\title{
MACHADO DE ASSIS: UM ESCRITOR ALÉM DE SEU TEMPO E DE SEU PAÍS
}

\author{
Juracy Assmann Saraiva \& \\ Marinês Andrea Kunz \\ Centro Universitário Feevale
}

Machado de Assis é acusado por muitos críticos, particularmente por seus contemporâneos, de se manter alheio à sociedade brasileira e aos problemas sociais e economicos de seu tempo, como o da escravidão. Paralelamente, releituras atuais de suas obras nelas identificam um posicionamento aberto e franco contra o status quo, criando a imagem de um escritor combativo, que teria se valido da literatura para denunciar a condição subhumana a que os escravos eram submetidos. Machado de Assis inscreve, em sua obra, uma critica às injustiças sociais $e$, ao interpretar a sociedade brasileira, expressa suas posições com sutileza, inoculando-lhes uma perspectiva irônica. Todavia, distinguindo-se dos escritores a ele contemporâneos, não se restringe à representação de problemas locais, mas focaliza a existência humana, transcendendo, por sua arte, seu tempo e seu país.

Palavras-chave: Machado de Assis, absenteísmo, universalidade.

\section{Entre o engajamento e a neutralidade}

O que se deve exigir do escritor, antes de tudo, é certo sentimento intimo, que o torne homem do seu tempo e do seu país, ainda quando trate de assuntos remotos no tempo e no espaço. (Machado de Assis)

A epígrafe, retirada do texto crítico "Literatura brasileira Instinto de nacionalidade", publicado por Machado de Assis, 
em 1873, na revista $O$ novo mundo de Nova Iorque, ganha novos contornos no momento em que a releitura de suas obras aponta para a adesão do escritor a determinados posicionamentos político-ideológicos. Essas atualizações da produção machadiana, sustentadas por uma visão sociológica ou histórica da literatura, contestam a neutralidade do escritor em face dos acontecimentos da vida brasileira e se contrapõem à opinião dos que lhe atribuíram um desinteresse pelas coisas de seu tempo e de seu país.

As posições suscitadas por essas duas interpretações antagônicas ignoram, porém, a natureza da literatura, cujas manifestações trazem em si as marcas da historicidade, sem, contudo, restringir-se a ela. As palavras que compõem o texto são tecidas a partir de uma multidão de fios ideológicos que servem para expor a trama das relações sociais (Bakhtin 42). Nesse sentido, os textos literários são um cronótopo, uma vez que traduzem um tempo e um espaço determinados e, dando lugar à emergência de diferentes discursos, figurativizam questões políticas, morais, éticas e estéticas.

Machado de Assis enfoca a sociedade brasileira da segunda metade do século XIX e se revela um atento e perspicaz observador da moral, dos costumes e das relações humanas. Entretanto, ainda que seus personagens circulem pelas ruas, praças e demais logradouros da cidade do Rio de Janeiro e que os ritos sociais desse lugar e dessa época estejam representados, Machado expõe a dimensão da pluralidade e da universalidade humana. As menções a formas particulares da estrutura e da organização social, aos aspectos culturais e aos dados da espacialidade solidificam os efeitos de realidade de sua obra ficcional, contribuindo para a verossimilhança, mas as tramas reveladoras das ações humanas transcendem o localismo para representar "a essência da própria humanidade" (Broca 13), que é idêntica em toda e qualquer latitude.

Paralelamente, Machado de Assis concebe seus textos como um espaço da linguagem em que se entretecem campos discursivos diversos que traduzem uma multiplicidade de pontos de vista, os quais devem ser recuperados pelo leitor para que, a partir do ato da leitura, 
compartilhe da análise do homem e da sociedade, a que o escritor procede.

Apesar de criar a representação de um mundo em que diferentes ideologias entram em conflito, Machado de Assis foi considerado, por muitos críticos, um escritor que se distanciava de problemáticas a ele contemporâneas, como a do sistema político brasileiro e de sua estrutura econômica. Além disso, ele foi cobrado de ter sido alheio, principalmente, ao sofrimento dos afrodescendentes, grupo de que fazia parte, naquela sociedade extremamente estratificada, quando estavam em voga teorias racistas que sustentavam a supremacia do branco sobre os demais grupos étnicos. A ideia do distanciamento machadiano funda-se, de um lado, em seu estilo discreto de vida e na austeridade que o caracterizava. De outro, é baseada no horizonte de expectativas dos leitores de sua época, já que sua análise do cenário social, e da elite fluminense, nem sempre foi percebida devido à fina ironia e sutileza com que ele a retrata, diferenciando-se, assim, do paradigma das produções realistas que constituía a base de referência para os consumidores de literatura. ${ }^{1}$

\section{A imagem do escritor entre os interstícios das obras}

As razões para conceber a imagem de Machado de Assis como alheio à realidade brasileira foram sendo construídas pela crítica ao longo do tempo, mesmo por aqueles que quiseram enaltecer $o$ valor de sua obra no panorama nacional.

Analisando a biografia de Machado de Assis, constata-se que seu comportamento, na maturidade, é distinto daquele assumido como jornalista na juventude, quando, absorvido pela política, opõe-se de modo explícito tanto a indivíduos quanto ao regime conservador. Entretanto, a partir do

\footnotetext{
${ }^{1}$ Machado de Assis recusa-se a aderir ao cânone realista e naturalista, tendo em vista que, em suas obras, recupera a tradição da literatura ocidental que privilegia a imaginação e o jogo lúdico da linguagem, em detrimento da "objetividade" própria a uma literatura que intenta aproximar-se da realidade. Esse tema é abordado por Carlos Fuentes e por Regina Zilberman.
} 
momento em que optou pela literatura, o ficcionista já não se envolvia de modo panfletário e direto em questões polêmicas, como a da abolição da escravatura, tal qual o faziam muitos escritores e intelectuais de seu tempo. Ele o fazia, contudo, de modo sutil na tessitura ficcional e até silenciosamente na função de funcionário público, sem que sua ação revolucionária fosse percebida por seus críticos, como, por exemplo, José do Patrocínio, que defendia abertamente a abolição da escravatura e denunciava a impassibilidade de Machado:

O país inteiro estremece; um fluido novo e forte, capaz de arrebatar a alma nacional, atravessa os sertões, entra pelas cidades, abala as consciências... Só um homem, em todo o Brasil e fora dele, passa indiferente por todo esse clamor e essa tempestade... Esse homem é o Sr. Machado de Assis. Odeiem-no porque odeia a sua raça, a sua pátria, o seu povo (cit. em Meyer 39).

Entretanto, a imagem do escritor imune aos aspectos impactantes da realidade brasileira viria ser composta, não apenas por seus detratores, entre os quais se inscreviam Sílvio Romero, José do Patrocínio, Cruz e Souza, Tobias Barreto, Hemetério dos Santos (Grieco 161), mas também por aqueles que desejavam enaltecê-lo.

Críticos contemporâneos a Machado, Sívio Romero e José Veríssimo tratam do tema da nacionalidade, orientando-se por objetivos distintos: o primeiro visa diminuir a importância da obra machadiana, e o segundo, exaltá-la. Romero declara que o escritor retratou a sociedade fluminense, pela "criação de verdadeiros tipos sociais e psicológicos, que são nossos em carne e osso, e essas são as criações fundamentais de uma literatura" (História 1620). Ele relaciona a presença do aspecto nacional à origem étnica, ao destacar que "o nisus central e ativo de Machado de Assis era de brasileiro, e como tal se revelava no caráter essencial de sua obra de mestiço e até em várias roupagens exteriores, quando assestava a observação mais diretamente para cousas pátrias" (História 1636). Embora qualifique o escritor como o nosso "mais completo espécime do homem de letras" e refira sua paixão pela "difícil arte da escrita", nega-lhe as 
qualidades do estilo, visto que opõe à correção a ausência de colorido, a pobreza de vocabulário, a falta de imaginação, expressa na monotonia das idas e vindas e na impressão de um "perpétuo tartamudear" (Machado de Assis 15). Rejeita igualmente qualidades do humor machadiano e sua concepção pessimista sob o argumento de que "não é natural e espontâneo; é um capricho, uma cousa feita segundo certas receitas e manipulações" (História 1628), pois "nós brasileiros não somos em grau algum um povo de pessimistas" (História 1630). Para Romero, o humor de Machado é uma imitação pouco hábil de Sterne, contrária à índole do escritor e do povo, enquanto o pessimismo resulta de um exercício de racionalização, sendo, portanto, artificial.

José Veríssimo contesta Sílvio Romero, porque considera a sátira a "íntima feição do gênio da obra do Sr. Machado de Assis", que decorre de "sua concepção de vida, amarga como a de um pessimista de condição e temperamento, mas retida na sua expansão" (Estudos Vol.4 104). Quanto ao estilo, Veríssimo defende a opinião segundo a qual Machado foi um pioneiro, dotado de "bom gosto e de medida, não foi nunca nem um servil imitador do estilo propriamente português, nem macaqueador dos clássicos, nem um revoltoso contra as sãs tradições e a boa disciplina da língua vernácula" (Estudos Vol.4 105).

Para o crítico, essas virtudes fazem de Machado o primeiro "psicólogo" da sociedade brasileira, visto que "deu da alma brasileira a notação mais exata e mais profunda" (Estudos Vol.4 106). Nesse sentido, afirma que Machado é o único escritor brasileiro que aborda o geral, o humano, sem ater-se a questões "etnográficas e locais", pois a " flexibilidade do seu talento permite-lhe casar perfeitamente a verdade geral e superior da natureza humana, com a verdade particular do temperamento nacional" (Estudos Vol.3 29).

A complexa relação entre o local e o universal, entre a representação da brasilidade ou de sua ausência, presente na crítica do final do século XIX, dá lugar a novos ângulos de análise com os biógrafos de Machado de Assis. Dentre esses, um dos primeiros que contribuiu para a ideia do absenteísmo machadiano foi Alfredo Pujol, que, em 1917, publica a 
biografia intitulada Machado de Assis. Pujol enfatiza elementos dramáticos da vida do escritor, destacando seu sucesso pessoal e profissional apesar de sua difícil história de vida, marcada pela ascendência negra, pela condição social, pela orfandade e pela doença, mas ignora a importância da associação de Machado a grupos adeptos da fé democrática e liberal e a manifestação de seus posicionamentos ideológicos durante a juventude.

Para confirmar a imagem de Machado de Assis como um escritor que se preocupa com o esteticismo e não com a realidade social, Pujol destaca, em sua obra, a influência de escritores clássicos como Montaigne, Shakespeare, Sterne, Stendhal, entre tantos outros, embora saliente sua independência diante dos preceitos literários. Afirma, ainda, que "em todos os seus livros avulta o estudo da vida fluminense e dos tipos da sua galeria humana, nas diversas épocas da nossa evolução política e social, e nos vários costumes e usos de cada tempo" (213). Apesar disso, Pujol analisa de forma limitada os textos machadianos, pois, reduzindo-os a uma significação linear, não assinala a ambiguidade neles reinante, em que o posicionamento político está expresso de forma alegórica (Saraiva, Circuito).

Ao enfatizar que o escritor não teria outra paixão além de sua arte, Pujol fixa a imagem do homem isento e racional, sendo responsável pela propagação do mito do escritor ausente. O biógrafo, ainda que desejasse enaltecer Machado de Assis, propaga a ideia de seu absenteísmo político e social, influenciando gerações de críticos e de leitores.

Tal concepção viria a ser subvertida por Lúcia Miguel Pereira, que publicou, em 1936, uma biografia do escritor, a que ela mesma atribui um caráter interpretativo. A autora busca a vida de Machado na obra e a obra na vida, enfatizando as dificuldades por que ele passou. Apoiada em trechos da ficção do autor, preenche dados da infância e lê os romances da primeira fase como confissões autobiográficas, reveladoras do desejo de ascensão social do escritor.

Ao tentar desfazer a lenda do "homem frio, indiferente, impassível" (16), Lúcia Miguel Pereira revelou o contato intenso do escritor com a vida e, mesmo não tendo 
alcançado, nas obras, o indivíduo real como pretendia, aprofundou o conhecimento das produções machadianas ao nelas iluminar sentidos vários. Centrando-se na figura humana que ela abstrai das obras ficcionais, a biógrafa, ainda que por um caminho inverso ao de Alfredo Pujol, também salienta a omissão do escritor diante dos problemas da sociedade brasileira, pois a produção machadiana constituise, para ela, em material autobiográfico em que Machado revela sua subjetividade.

Sem adotar o ângulo biográfico, mas seguindo a mesma linha de Lúcia Miguel Pereira, o intérprete da obra machadiana Augusto Meyer destaca que Machado de Assis

Não pintou, portanto, o Rio do seu tempo, nem a gente, nem o ambiente do seu tempo, senão para poder mais livremente cultivar a sua paixão da análise psicológica, desabafo indireto e velado, às vezes inconsciente, do seu pessimismo (138-139).

Entretanto, ainda sob a perspectiva biográfica, outros autores negam o isolamento machadiano, contrariando o posicionamento de Alfredo Pujol e de Lúcia Miguel Pereira. Jean-Michel Massa apresenta o escritor combativo do Diário do Rio de Janeiro e demonstra como, pouco a pouco, o escritor se instituía em dramaturgo, poeta, crítico e contista. Acompanhando esse desenvolvimento progressivo, o pesquisador francês relaciona-o tanto a acontecimentos quanto à determinação de objetivos pessoais, cuja realização é alcançada pelo trabalho intelectual e, dessa forma, a imagem que Massa constrói "é o inverso do Machado de Assis que a crítica nos legou [...]. Machado de Assis é, ponto por ponto, o contrário do mito: corajoso, ativo, engajado, idealista" (309).

Raimundo Magalhães Júnior conjuga relações possíveis entre dados biográficos e dados das produções machadianas, analisando, ainda, acontecimentos históricos e seu reaproveitamento. Portanto, o biógrafo, sem ater-se ao envolvimento do escritor com a política brasileira, estabelece vínculos entre o objeto representado e o de representação, comprovando que Machado procede à análise da realidade 
brasileira para transferi-la, alegoricamente, para o âmbito ficcional.

O ensaísta Brito Broca também rebate a ideia do absenteísmo de Machado de Assis, demonstrando sua combatividade por meio da transcrição de trechos de artigos publicados pelo autor em diferentes periódicos, como o Diário do Rio de Janeiro ${ }^{2}$. Referindo-se à acusação que recaíra sobre Machado de mostrar-se indiferente quanto ao problema da escravatura, Broca afirma que muitos escritores mulatos, como Tobias Barreto, haviam traído a causa do negro em busca de ascensão social. Entretanto, por não terem alcançado a qualidade estética e o reconhecimento de Machado, essa traição não lhes fora cobrada. Explica, ainda, que apenas em 1875 iniciava a campanha em prol da libertação dos escravos, cujo impulso se deu realmente em 1881. Assim, o crítico conclui que antes de 1875 não era possível a Machado lutar pela causa e que, em 1881, ele já não era jovem o bastante para tal empreendimento. Além disso, argumenta que o escritor já tinha entrado na fase do desencanto, quando via tudo pela ótica da ironia e do pessimismo. Por fim, afirma não ser possível imaginar Machado de Assis no palanque a discursar inflamadamente pela causa, já que isso seria inverossímil em se tratando de pessoa tão reservada como ele.

Apesar disso, Broca aponta na literatura machadiana marcas do engajamento do escritor na luta contra a escravidão e o preconceito, como os contos "Pai contra mãe", "O caso da vara", "Mariana" e o poema "Sabina". No mesmo sentido, também destaca passagens de romances em que Machado denuncia o comportamento contraditório dos indivíduos como o da personagem Cotrim, de Memórias Póstumas de Brás Cubas. O crítico destaca a contradição desse representante típico da elite escravista que, de um lado, manda, sem o menor sinal de culpa, fustigar duramente escravos recém-contrabandeados que não haviam cometido

\footnotetext{
${ }^{2}$ Exemplo de sua combatividade é a crônica Canção de Piratas, publicada no dia 22 de julho de 1894, em que aborda o episódio de Canudos e o grupo de Antônio Conselheiro.
} 
nenhum delito, enquanto, de outro, demonstra seu profundo amor pelos filhos, revelando ser um pai exemplar.

Em Memorial de Aires, Broca identifica a crítica de Machado à classe dominante quando aborda a libertação dos escravos pelo fazendeiro Santa Pia e a posterior doação da fazenda aos antigos escravos por parte de sua filha Fidélia. Com o episódio, Machado denuncia a prepotência do proprietário e a falsa bondade da herdeira em seus atos aparentemente magnânimos, já que o pai de Fidélia liberta os escravos por vontade própria apenas para não ser obrigado a fazê-lo por lei, enquanto ela lhes transfere uma propriedade que se transformara em um problema, desde que decidira abandonar o Brasil para residir em Portugal.

Paralelamente a essas remissões a textos, o crítico pergunta como seria plausível acusar de absenteísta o escritor que analisara a sociedade fluminense, retratando seus costumes e as instituições que a regiam. Afirma que Machado não toma partido, não defende nem ataca indivíduos e instituições, mas "mantém-se na legítima posição do artista, visando, acima do particular ou do nacional o universal, acima do homem brasileiro, a essência da própria humanidade" (Broca 13). Conclui, pois, que o escritor não se manteve alheio a seu tempo, mas que o representou naquilo que resguarda do plano universal.

Seguindo o caminho aberto por Brito Broca, outros críticos reavaliam a atuação de Machado de Assis e sua produção, como Roberto Schwarz, Sidney Chalhoub e Eduardo de Assis Duarte. Em "Duas notas sobre Machado de Assis", Schwarz retoma a divergência de posicionamentos críticos segundo os quais haveria "em Machado a falta da intenção e do colorido nacional" ou, ao contrário, ele seria "o mais profundamente brasileiro de nossos escritores" (165). Para Schwarz, "as duas convicções registram a posição diminuída que acompanha a notação local no romance de Machado" (168), desconhecendo, porém, que há uma grande evidência de detalhes do contexto social do Rio de Janeiro, cuja percepção não é salientada, devido "ao contraste escarninho com os assuntos ditos universais a que ela serve de matéria" (168). Concluindo seu artigo, o crítico afirma que "o Brasil 
está retratado em profundidade" nos livros que Machado produziu entre 1880 e 1906; entretanto, "estes livros não são a representação direta de nenhuma das grandes correntes ideológicas que agitavam o momento. Não são adeptos da filosofia determinista [...], não são abolicionistas [...], não são republicanos [...], e não se curvam à escola triunfante do Naturalismo," ainda que tratem de todos esses assuntos sob uma perspectiva irônica (178).

Na obra Machado de Assis historiador, Chalhoub recupera o percurso do autor em sua função de funcionário público e mostra como ele atuava a favor dos desvalidos do sistema, sugerindo a aplicação rigorosa das leis que previam a libertação dos escravos, como a do "Ventre Livre". O autor relaciona a experiência de Machado no serviço público com sua obra literária: "o romancista formou-se e transformou-se ao longo dos anos de 1870 em diálogo constante com a experiência do funcionário público e do cidadão" (138-139).

Em Machado de Assis afro-descendente, Eduardo de Assis Duarte visualiza a obra de Machado de Assis como uma espécie de denúncia acerca das condições de vida dos negros. Para isso, compõe uma antologia de poemas, crônicas, contos, críticas teatrais e trechos de romances, entre os quais aqueles citados por Broca, com o objetivo de desmistificar a concepção do absenteísmo machadiano. Em sua análise, afirma que o autor se expressa

[...] à maneira do escritor-caramujo, sem a altissonância dos sermões, sem nenhum arroubo panfletário. Machado, em momento algum, submete sua ficção às exigências do discurso ideológico, com suas formulações marcadas pela urgência dos momentos de crise política. Deste modo, persiste nos romances o emprego dos procedimentos esquivos, que, em seu conjunto, compõem toda uma poética da dissimulação (272).

A remissão aos estudos desses quatro críticos deixa evidente o papel de Machado em relação não só à causa abolicionista, mas também em relação à própria condição de vida dos afrodescendentes, inclusive após o "Treze de Maio", o que caracteriza como inadequada a afirmação de que ele se mantinha distante da realidade. Esse posicionamento decorre do modo como sua obra foi 
interpretada, visto que ela foi lida ora como manifestação do escritor artesão, isento das paixões do mundo, ora como extensão de fatores biopsíquicos ou da interioridade do artista, ora como produto de um olhar arguto e crítico que sabia focar o espaço social, mantendo, contudo, a devida distância em relação a ele para poder captar sua singularidade.

Contudo, ainda que se destaque a importância dos estudos de Eduardo de Assis Duarte que provam cabalmente que Machado não se manteve indiferente à questão da escravatura, é necessário salientar que os textos do escritor brasileiro não podem ser reduzidos a esse ângulo temático. Contrariamente ao que propõe o ensaísta mineiro, Machado não se limita a denunciar o vergonhoso tratamento dispensado aos negros, já que seus textos não respondem apenas ao desafio de trazer à luz a reificação do homem embasada na diferença étnica, cujo cenário foi o Rio de Janeiro do século XIX. Ao relatar o tratamento dispensado aos afrodescendentes, Machado desnuda o ser humano e demonstra a crueldade de que ele é capaz, independentemente de sua origem étnica e de sua localização tempo-espacial.

\section{O olhar do escritor entre o próximo e o distante}

A análise de narrativas de Machado comprova que elas exploram temas contextualizados, mas esses se expandem para além dos limites que compõem o cenário das ações e os parâmetros da temporalidade. O conto "Pai contra mãe" pode ser lido como um libelo contra a escravidão no Brasil, como deseja Eduardo de Assis Duarte; todavia, nele há elementos que transcendem o contexto sócio-políticocultural que aí está explícito. O conto inicia com a descrição dos aparatos de tortura com que eram punidos os escravos e com a menção ao ofício de caçador de negros fugitivos que, segundo o narrador, não "seria nobre, mas por ser instrumento da força com que se mantêm a lei e a propriedade, trazia esta outra nobreza implícita das ações reivindicadoras" (Assis, Contos 484). 


\section{Saraiva \& Kunz}

Em seguida, o caçador de escravos Cândido Neves é apresentado ao leitor como um sujeito inapto para outros trabalhos, já que "carecia de estabilidade" nos empregos e era orgulhoso demais para atender e servir. A ironia com que o narrador expusera o ofício, já extinto no momento da enunciação, estende-se à constituição sígnica do protagonista e se mostra enfática em sua designação. O caçador de escravos fugidios não se mostra cândido, mas capaz de violência extrema, além de não ser sem máculas, como sugere o termo neves. Tal reflexão se estende à esposa, cujo nome - Clara - reitera a aparente noção de transparência e de pureza. Pode-se, contudo, relacionar o nome Cândido à ingenuidade com que a personagem acredita poder solucionar seus problemas, não percebendo que está inserido em contexto sócio-histórico excludente.

Quando nasce o primeiro filho do casal Cândido e Clara, a situação econômica da família fica insustentável. Por já não terem onde morar, Mônica, a tia de Clara, pressiona Candinho a entregar a criança à Roda dos Enjeitados, o que o faz reunir todas as suas forças, a fim de conseguir o dinheiro de que necessita para poder manter o filho junto a si. Na manhã em que entregaria o filho à Roda, Candinho captura a escrava fugida, Arminda, pela qual um anúncio oferecia considerável valor em dinheiro. A escrava está no final do período de gestação e resiste ao aprisionamento, vindo a abortar. Situa-se aí o impasse antecipado pelo título do conto, ou seja, ele narra a luta travada entre um pai e uma mãe e não apenas a solução do problema de Cândido Neves, a qual é conquistada com o aprisionamento de Arminda.

Os termos "pai" e "mãe" colocam em nível de igualdade as duas personagens: de um lado, o pai, que, embora seja branco, também está à margem da sociedade e, por conseguinte, está desamparado e desprovido de benesses sociais; de outro, a mãe, que é escrava e, assim, desvalida de qualquer direito, torna-se alvo "legítimo" das maiores crueldades. A oposição entre genitores é reforçada pelo narrador que, ao falar dos sentimentos de Cândido Neves quando busca seu filho com o farmacêutico, usa o termo "pai” e não o nome próprio da personagem: "o pai recebeu o 
filho com a mesma fúria com que pegara a escrava fujona de há pouco, fúria diversa, naturalmente, fúria de amor" (Assis, Contos 494).

O texto enfoca a questão da escravidão no Brasil, mas, para além dela, concentra-se na luta entre pais que buscam garantir a sobrevivência dos filhos e usufruir de seu convívio, o que expande o eixo temático para inseri-lo no âmbito do humano: o sentimento de posse inalienável dos pais e das mães em relação aos filhos. O conflito instaurado é, portanto, ontológico, e as personagens são concebidas como signos que figurativizam a paternidade $\mathrm{e} a$ maternidade. Nessa luta, vence momentânea e aparentemente aquele que, mesmo situado na marginalidade, é o mais forte.

$\mathrm{O}$ conto termina com a revelação do raciocínio compensatório do protagonista ao perdoar a si mesmo pelo infortúnio que trouxera a Arminda: "Nem todas as crianças vingam" (Assis, Contos 494). ${ }^{3}$ Porém, sob o aspecto da sobrevivência, o papel de tia Mônica também é fundamental, pois ela mostra que o filho de Cândido Neves está condenado antes mesmo de seu nascimento. Ela adverte, já no início da vida conjugal de Cândido e Clara, que um filho seria em grande problema. Entretanto, quando o protagonista traz o filho após a captura de Arminda, a tia perdoa-lhe o retorno, "uma vez que trazia os cem mil-réis" (Assis, Contos 494). Desse modo, ela situa a criança na condição de um escravo, já que apenas pode pertencer à família mediante a garantia do dinheiro. Portanto, no conto, a permanência da criança branca no reduto familiar é comprada pelo pai, que paga esse direito com a gratificação recebida do proprietário por ter a escrava de volta. Em outras palavras, a vida do filho de Cândido Neves custa a vida do filho de Arminda, mas a contraposição das duas situações comprova que elas se equivalem: de um lado, está a reificação do ser humano e sua

\footnotetext{
${ }^{3}$ A reflexão de Cândido Neves remete à teoria da equivalência das janelas de Brás Cubas, segundo a qual a consciência, como uma sala, deve estar sempre arejada: ao se fechar uma janela, deve-se abrir outra. Assim, a morte do filho da escrava é justificada pelo protagonista por um dado biológico, o qual lhe permite sopitar qualquer sentimento de remorso ou, nas palavras de Brás Cubas, abrir uma janela.
} 


\section{Saraiva \& Kunz}

aniquilação, instaladas pelo regime escravocrata; de outro, a pobreza que, como instrumento de seleção das espécies, permite que apenas os mais aptos sobrevivam. Arminda e Cândido Neves são ambos prisioneiros de um sistema em que a sobrevivência se sustenta na capacidade de gerar dinheiro. Logo, uma vez que os "cem mil-réis" da gratificação tenham sido consumidos, o filho de Cândido será rejeitado ou, tal qual o filho de Arminda, condenado à morte, para que sobrem mais alimentos a seus pais e a tia Mônica, repetindo-se o processo humano de devoração do mais frágil pelos mais fortes.

Outro conto em que Assis Duarte verifica a existência de um posicionamento favorável de Machado de Assis à libertação dos escravos tem "O Espelho" por título. Neste, Jacobina, o protagonista-narrador, defende a ideia de que cada ser é constituído por uma alma interna e outra externa. Para comprová-la, conta o episódio de sua nomeação ao posto de alferes, marcada pelo orgulho da família, pelo despeito dos demais concorrentes, pela inveja de alguns amigos e pela satisfação de outros que lhe dão a farda de presente. Por compartilhar do orgulho da família, uma tia de Jacobina convida-o a visitá-la em seu sítio, recomendando, porém, que leve a farda. Tal qual a mãe, a tia passa a chamálo de alferes, denominação assumida pelos demais habitantes do sítio. Todos demonstram a importância que atribuem à patente, manifestando-a por atenções, obséquios, carinhos. Entre esses, destaca-se a decisão da tia de colocar no quarto do jovem a melhor peça da casa: um espelho.

Passadas três semanas, o jovem estabelece sua relação com o mundo apenas por meio das referências ligadas ao exercício da patente, e, em consequência disso, o alferes elimina o homem. Inesperadamente, a tia é obrigada a ausentar-se da fazenda. A esse afastamento soma-se a fuga dos escravos, ficando o alferes envolvido pela mais completa solidão. A ausência da admiração coletiva, que sustentava sua "alma exterior", leva-o a vivenciar um sentimento de opressão e a experimentar a sensação de ser um "defunto", um "sonâmbulo", um "boneco mecânico" (Assis, Contos 408). Somente o sono assegura-lhe alívio, pois farda-se em 
sonhos e neles recolhe os elogios e as promessas de ascensão na hierarquia militar.

A inquietação que o domina afasta-o do espelho pelo receio que alimenta de visualizar-se, simultaneamente, como um e dois. Entretanto, ao fim de oito dias, movido pela contradição humana, busca sua imagem no espelho com o objetivo de nele captar a dualidade, antes recusada. Surpreendentemente, a imagem esperada perde-se em névoas de sombra, provocando a estupefação do protagonista: "Olhei e recuei. O próprio vidro parecia conjurado com o resto do universo; não me estampou a figura nítida e inteira, mas vaga, esfumada, difusa, sombra de sombra" (Assis, Contos 409).

Diante da difusão de linhas, da decomposição dos contornos de sua própria imagem, o alferes lembra-se de vestir a farda, e seus olhos encontram, então, "a figura integral" (Assis, Contos 410) ou, noutras palavras, captam novamente a "alma exterior", recolhida no espelho, restabelecendo-se o sentimento de completude.

Segundo Assis Duarte, o conto mostra a dependência do proprietário de seus escravos, uma vez que, sozinho, Jacobina não consegue nem ao menos prover sua comida. Sem dúvida, a fuga dos escravos e a incapacidade do protagonista revelam que aos cativos cabiam todas as tarefas e que o proprietário não realizava nem mesmo as mais simples atividades domésticas, pois até mesmo não sabia como fazê-las.

No entanto, essa ideia da dependência dos proprietários não é o fulcro temático do conto, que consiste, sobretudo, em uma reflexão sobre a relação do sujeito com o outro e a necessidade das relações intersubjetivas na construção da identidade do eu. Jacobina perde os próprios referenciais, porque não havia ninguém mais ao seu redor - "Nenhum ente humano" (Assis, Contos 407) - que lhe pudesse devolver a imagem de si mesmo, nem sequer os escravos, que, segundo observa, também lhe reforçavam a alma externa. O conto discute, portanto, a perda das referências do eu, as quais são construídas pela atitude avaliativa do outro, tema filosófico e universal que, portanto, não se restringe à 


\section{Saraiva \& Kunz}

exposição da dependência do senhor de escravos em relação a esses.

Simultaneamente, ao esboçar, em "O Espelho", o esboço da teoria da alma de forma alegórica, Machado de Assis

denuncia o jogo especular de aparências que, sobrepostas umas às outras, esmaecem a verdade do sujeito, dela preservando apenas reflexos irisados. Assim, o processo de fragmentação da identidade, ficcionalmente concebido, transcende o episódio narrado para abarcar os homens em geral, uma vez que a dualidade da alma corresponde à representação desdobrada do homem, cindido entre o ser e o parecer (Saraiva, "O espelho" 147).

A ambiguidade da produção machadiana, que instala a possibilidade de múltiplas leituras, exige que o leitor correlacione a significação explícita de episódios e de acontecimentos com a totalidade do texto, para, então, alcançar sua significação encoberta. Assim, a denúncia da escravidão como um processo de aviltamento do humano pode expandir-se para referir um comportamento instintivo que transforma um escravo impotente em um impiedoso senhor, quando tem em mãos o vergalho, isto é, o poder de subjugar e castigar. Exemplo disso são os capítulos XI, XLVI e LXVIII, de Memórias póstumas de Brás Cubas, intitulados, respectivamente, "O menino é pai do homem", "Herança" e "O vergalho". O primeiro deles expõe a deficiente educação recebida pelo protagonista quando criança e assinala o tratamento impiedoso que ele impõe a um escravo da casa, rebaixado à condição de animal, conforme o relato elucida:

Prudêncio, um moleque da casa, era o meu cavalo de todos os dias; punha as mãos no chão, recebia um cordel nos queixos, à guisa de freio, eu trepava-lhe ao dorso, com uma varinha na mão, fustigava-o, dava mil voltas a um e outro lado, e ele obedecia, - algumas vezes gemendo, - mas obedecia sem dizer palavra, ou, quando muito, um - "ai, nhonhô!" - ao que eu retorquia: "- Cala a boca, besta!" (Assis, Obra completa 526527.) 
No capítulo mencionado, o narrador relata, também, que quebrara a cabeça de uma escrava, porque ela lhe negara uma colher do doce que fazia, e colocara cinza no tacho, dizendo à mãe que a escrava é que estragara o doce "por pirraça". Ambos os episódios evidenciam que os escravos eram vítimas de maus tratos, sendo até mesmo reduzidos à condição de brinquedos, com que "os meninos diabos" exercitavam sua maldade, ou de objetos de barganha. Esse ponto de vista é corroborado pelo capítulo XLVI que expõe a disputa pela herança paterna entre Brás Cubas, Sabrina, sua irmã, e Cotrim, o cunhado, ocasião em que Prudêncio é mencionado como um objeto, entre os demais, que deveriam ser divididos. Após saber que Prudêncio fora alforriado pelo pai de Brás, Cotrim, demonstrando sua ganância e a total incapacidade de reconhecer traços humanos no ex-escravo, estabelece um confronto entre esse e a baixela de prata, declarando: "Como seu pai arranjava estas coisas cá por casa, sem dar parte a ninguém! Está direito. Quanto à prata... creio que não libertou a prata?" (Assis, Obra completa 562563).

A reificação do homem pelo homem retorna, porém, no capítulo LXVIII, em que Brás Cubas se surpreende com o espancamento de um preto por outro preto. $\mathrm{O}$ que tinha o vergalho na mão não atendia às suplicas do que apanhava, a elas respondendo com novas agressões. Ao ouvir as palavras que ele mesmo dizia em criança - Cala a boca, besta! -, Brás reconhece Prudêncio e pede-lhe que perdoe a seu escravo e analisa a cena da seguinte forma:

Era um modo que o Prudêncio tinha de se desfazer das pancadas recebidas, transmitindo-as a outro. Eu, em criança, montava-o, punha-lhe um freio na boca e desancava-o sem compaixão; ele gemia e sofria. Agora, porém, que era livre, dispunha de si mesmo, dos braços, das pernas, podia trabalhar, folgar, dormir, desagrilhoado da antiga condição, agora é que ele se desbancava: comprou um escravo, e ia-lhe pagando, com alto juro, as quantias que de mim recebera (Assis, Obra completa 582).

Postos em confronto, os capítulos ganham nova significação. Entre o capítulo em que Prudêncio é espancado 
e aquele em que ele próprio tem o vergalho na mão, situa-se o capítulo denominado "Herança", termo cuja significação recai sobre o capítulo anterior e sobre o subsequente, acrescentando-lhes uma pluralidade de sentidos. Com efeito, a herança é tanto a que Brás recebe quanto a que ele transfere a Prudêncio, enquanto este paga "com alto juro" as "quantias" ou as maldades que lhe haviam sido aplicadas, comprovando que, sob a perspectiva do narrador, a maldade é inata ao homem, sendo transferida de um ao outro. Assim, Prudêncio não representa apenas o escravo vilipendiado por seu proprietário, pois ele é, também, o proprietário que faz valer seus direitos sobre outro escravo; sendo parte de uma cadeia evolutiva, ele conjuga a condição de vítima e agressor, condição cuja permanência é garantida pela "herança" que recai sobre o gênero humano.

Com Memórias póstumas de Brás Cubas, Machado de Assis não tem o objetivo de edificar, converter ou reconfortar os homens, mas colocá-los frente a sua própria miséria e a condição de escravo dela faz parte. Entretanto, a transcendência que caracteriza esse romance e, em particular, os capítulos analisados, não nos permite afirmar que aí se constrói apenas um libelo contra o regime escravista brasileiro. Neles também se denunciam diferentes formas de grilhões que podem ter o nome de poder, ascensão social, posse de bens materiais e o aprisionamento à própria natureza humana.

Segundo Antonio Candido, a polissemia que Machado de Assis conferiu a seus textos permite que "cada grupo e cada época encontrem as suas obsessões e as suas necessidades de expressão" nelas representadas e que o escritor seja valorizado "por motivos diversos", em razão de "qualidades por vezes contraditórias" ("Esquema" 18). Ao possibilitar inúmeras leituras, a ambiguidade é fator de enriquecimento semântico que abre o texto a variadas interpretações e lhe garante sua permanência ou a atemporalidade que caracteriza as obras de arte clássicas. Por sua capacidade de suscitar várias e novas interpretações que, sob o prisma político, vão da neutralidade ao engajamento, a obra de Machado de Assis sobrevive, adaptando-se ao espírito de novos tempos. 
Entretanto, as posições antinômicas aqui referidas parecem ignorar a natureza polissêmica do texto machadiano e a função da literatura, visto que a reduzem a um instrumento de conscientização de problemas sociais. Contrariamente aos críticos que afirmam o absenteísmo do escritor e contrariamente aos que relacionam seus textos apenas a problemas conjunturais da sociedade brasileira do século XIX e do início do século XX, defende-se aqui a posição de que Machado de Assis dialogou com seu momento histórico e retratou a sociedade em que vivia, mas que, simultaneamente, ultrapassou seu tempo e seu espaço ao enveredar pela essência do humano. Com efeito, Machado não optou pela defesa de determinadas linhas ideológicas nem de determinados grupos, pois, ao analisar e denunciar as mazelas da sociedade brasileira, deu forma a temas universais.

"Enigmático e bifronte, olhando para o passado e para o futuro, escondendo um mundo estranho e original" (Candido, "Esquema" 17), ele representou "conflitos essenciais do homem consigo mesmo, com os outros homens, com as classes e os grupos" (Candido, "Esquema" 32). Nesse processo de representação, cruzam-se, em sua obra, sentidos explícitos e outros encobertos: aqueles se enraízam na sociedade brasileira, podendo constituir denúncias em relação a procedimentos sociais; esses sugerem uma neutralidade aparente ou alongam a compreensão das representações e das denúncias, deslocando-as espacial e temporalmente. Articulados na totalidade da obra, os sentidos instalam "a função integradora e transformadora" da criação literária que "não corrompe, nem edifica [...] mas humaniza em sentido profundo" (Candido, "A literatura" 82-84). Portanto, sem negar sua inserção na realidade brasileira - que expressa, também, por um "certo sentimento íntimo" ("Instinto de nacionalidade" 817) - Machado de Assis transpõe os limites 
de seu tempo e de seu país, ao possibilitar uma maior inteligibilidade do homem. ${ }^{4}$

Obras citadas:

Assis, Machado de. Contos: uma antologia. São Paulo: Companhia das Letras, 2001. v.1.

---. Obra completa. Rio de Janeiro: Nova Aguilar, 1986,

---. "Instinto de nacionalidade". Obra completa. Rio de Janeiro: Nova Aguilar, 1986, v.3.

Bakhtin, Mikhail. Marxismo e filosofia da linguagem. São Paulo: Hucitec,1988.

Broca, Brito. Machado de Assis e a política e outros estudos. Rio de Janeiro: Organização Simões Editora, 1957.

Chalhoub, Sidney. Machado de Assis historiador. São Paulo: Companhia das Letras, 2003.

Candido, Antonio. "A literatura e a formação do homem." Textos de intervenção. São Paulo: Duas Cidades/ Editora 34, 2002.

---. "Esquema de Machado de Assis." Vários escritos. Rio de Janeiro/ São Paulo: Ouro sobre Azul/ Duas Cidades, 2004.

Duarte, Eduardo de Assis. Machado de Assis afrodescendente: escritos de caramujo (antologia). Rio de Janeiro/ Belo Horizonte: Pallas/ Crisálida, 2007.

Fuentes, Carlos. "O Milagre de Machado de Assis". Folha de São Paulo 1 out 2000: mais! 6.

Grieco, Agrippino. Viagem em torno de Machado de Assis. Rio de Janeiro: José Olympio, 1969.

Magalhães Júnior, Raimundo. Vida e obra de Machado de Assis. Rio de Janeiro: Civilização Brasileira, 1981.

Massa, Jean-Michel. A juventude em Machado de Assis. Rio de Janeiro: Civilização Brasileira, 1971.

\footnotetext{
${ }^{4}$ Artigo produzido no âmbito do projeto de pesquisa Concepções de leitura $e$ de literatura e sua inscrição na ficção machadiana, que conta com o apoio do CNPq e da Fapergs.
} 
Meyer, Augusto. Machado de Assis. Porto Alegre: Instituto Estadual do Livro, Corag, 2005.

Pereira, Lúcia Miguel. Machado de Assis: estudo crítico e biográfico. São Paulo: Editora Companhia Nacional, 1939.

Pujol, Alfredo. Machado de Assis. Rio de Janeiro: José Olympio, 1934.

Romero, Sílvio. História da literatura brasileira. Rio de Janeiro: José Olympio, 1954, v.5.

---. Machado de Assis. Rio de Janeiro: José Olympio, 1936.

Saraiva, Juracy Assmann. "O espelho ou a representação da ilusão." Nonada Letras em Revista 2 (1999): 139-147.

---. Circuito das memórias. São Paulo: Edusp/Nankin, 2009.

Veríssimo, José. Estudos de literatura brasileira, Vol.3. Belo Horizonte/ São Paulo: Itatiaia/ EdUSP, 1977.

---. Estudos de literatura brasileira, Vol.4. Belo Horizonte/ São Paulo: Itatiaia/ EdUSP, 1977.

Zilberman, Regina. "Memórias póstumas de Brás Cubas: diálogos com a tradição literária." Veredas: Revista da Associação Internacional de Lusitanistas 1.1 (1998): 179194. 